\title{
El aire y la piedra
}

Francine Masiello

Universidad de California

Empedrado abajo, la muerte toca el violín.

Malú Urriola

Me la paso observando las calles vacías durante la cuarentena de 2020: los negocios cerrados, las hojas de los periódicos volando por las veredas sin que nadie las recoja; las ratas que están de fiesta y corren con total libertad. Es cierto que estas son las dueñas de las vías ahora que los humanos se han ido. Pero, hacer acto de presencia de este concierto en gris mayor no provoca la alegría. De hecho, la caminata es incómoda; se respira la soledad. Apuro la vuelta a mi casa donde prendo la televisión a la espera del teleperiodista que me cuente los desastres del día: el número de muertos, el número de contagiados, el número de colegios que van a cerrar sus puertas para el inicio del año escolar. El presidente (a quien me niego a nombrar) repite por televisión que todos estamos bien, que Estados Unidos es el mejor país del mundo y que todo está bajo control; odio la monotonía de su voz, su mal humor, su falta de ética, su infatigable estupidez. No veo la hora en que se vaya. Cuento los días que le quedan hasta las elecciones de noviembre. Así yo también disfruto, a mi manera, de cierta fe en los números; en este caso, son el tamaño de mi esperanza.

Los días en casa son largos. Al principio, miraba las cuatro paredes sin leer, sin escribir, sin comunicarme con nadie. Enmudeció la creación. Tenía pocas ganas de acercarme a los amigos; los evitaba a más no poder. Quizás Agamben tuviera razón: "Al mantener la distancia social correcta, hacemos trizas el concepto del vecino". Es menos una estrategia; responde a nuestra tristeza. Mientras tanto, maldiciendo l'ennui invasor, descubro que el confinamiento me lleva a pensar el tiempo. Cuento las horas y los días. ¿Cuánto tiempo me quedará hasta que este contagio me mate? ¿Hasta que suba otra vez a un avión? ¿Hasta que vuelva a la biblioteca, al bar, al cine? Las gotas del tiempo pesan; siento su densa materia. El mes de marzo, por ejemplo, tenía 367 días; el mes de abril, 589; el mes de mayo, 1108. La numerología absurda define mi pesar, corresponde a las cifras absurdas de los muertos que aparecen cada noche en la tele: 7, 288, 639, 1408. En el día en que escribo 
esta nota, diagnosticaron positivos a más de seis millones de personas con por lo menos 200.000 muertos. Las estadísticas corresponden al deseo de aprehender el horror, de contenerlo todo en su cajita, comandado por el logos de los científicos pertenecientes al centro de control. Pero yo las veo como el pretexto para abrirme a los pequeños relatos posibles que definieran a los fallecidos; la soledad incógnita con que un célebre actor se acerca al momento de su muerte, el misterio de la transición entre cuerpo vivo y cadáver que envuelve a los pacientes mientras esperan su turno en la clínica; la angustia de la hija al despedirse por última vez de su madre. Los números no me cuentan esto; necesito como suplemento el arte de la ficción.

Para los vivos, los sobrevivientes debo decir, todo funciona al compás del tiempo lento. Es el tiempo de espera de los ancianos del geriátrico, sumergidos en su agonizante tristeza. Es el tiempo de espera de los niños migrantes aislados en sus jaulas, pequeñas cárceles que se sitúan en la frontera de Arizona con México. Ya enfermos de COVID, lloran la ausencia de sus padres, la necesidad de quien los abrace, la falta de cariño. Viven el tiempo del abandono en la más absoluta soledad.

Desde mi barrio, el silencio del mes de abril es interrumpido alegremente por el trinar de los pájaros. De repente, vuelven el tordo y el pájaro cardenal; los colibríes invaden los jardines y bailan alrededor de las camelias; eligen poner sus nidos en los patios de las casas. Hasta las monarcas, mariposas americanas en vías de extinción, han vuelto a ocupar un lugar en las pasifloras de la casa de al lado mientras los pavos silvestres salen en patota a retomar la calle. Saben los animales y los insectos que la especie humana tiene poco tiempo de vida; nuestro ciclo ha llegado a su fin. Así, toman la libertad de reclamar las avenidas, pierden el miedo al sujeto humano. Veo, por ejemplo, que ni la cierva ni su cría me llevan el apunte. Soy un detalle paisajístico más, como una hoja de árbol arrastrada por el viento. Soy un fleco en el ojo del otro, nada. La cierva me lo dice todo. Voy para el exterminio, pensará ella, mientras se pasea como la reina del barrio comiendo lo que encuentre, avanzando de un huerto a otro en busca de las delicias primaverales que cuelgan de los cerezos o de los albaricoqueros. Pero ya en estas semanas de agosto, mientras escribo este texto, los incendios de California destruyen campo y hogar. Los animales, como los seres humanos, nos reunimos bajo la sombra de esta nueva tragedia, densa e inesperada. Cantamos juntos el díes irae, cada uno en el lenguaje que le sirva.

Diamela me dijo una vez que la escritura es lo único que nos salva. Saber escribir garantiza la eternidad (o algo por el estilo; Diamela es siempre más articulada que yo). ¿Será asi? En los primeros meses de la pandemia, dudaba de semejante afirmación. Me costaba levantar la pluma, teclear ideas nuevas. Prefería el dolce far niente. Mirar el techo. Seguir las series. Experimentar el zigzageo de los días; esperar el abrir y cerrar de las noches. Dejé de ponerme el reloj pulsera. Olvidé el cantar de las horas. De repente, el mes de abril me llevó a cortar las distancias cuando los 
contactos con mi lejana infancia empezaron a llamarme. Allí, recuperé el diálogo con los primos en Italia. Es divertido, pensaba, retomar la conversa por Zoom. Empezamos a cocinar, juntos, pero a larga distancia. Juntos reproducimos tartas y dulces siguiendo las recetas antiguas de las tías que honraban en su cocina al santo de su elección. Cada uno en su hogar dando lecciones al otro. Desde lejos, Daniela corrige mi ignorancia respecto de la pasta choux; Mirella me recuerda que tengo que armar la masa siempre con los dedos mojados; las recetas que aparecen en Youtube, me dice, nunca son suficientes. Cómo traducir gramos a onzas, como entender el vocabulario extraño — tuorli, anido de mais, zucchero semolato-, cómo pasar de Fahrenheit a Celsius. Marco, un pasticciere oriundo de Savona, asume el papel de consejero principal; se auto-declara el maestro del show. Asegúrate de que la crema pasticciera no se pegue con el cuenco, solo usar cucharas de madera. Desde Bella, nuestro pueblo del sur, Enzo le contradice a Marco: no hay que agregar nunca el anido de mais. Y cuidado con el azúcar, agrega Pina desde Milán, porque todos estamos a dieta y ya sabes cuál es el problema.

Es agradable dialogar con ellos; se olvidan del peligro de la peste italiana, yo me olvido de la mía. Son maneras de conversar sobre la nada, de estar en contacto el uno con el otro, de convertir la banalidad de la comida en el pretexto de la fiesta familiar. El evento renueva nuestro pacto afectuoso, soldado ahora con azúcar y masa. Recuerdo la leve entonación que todos llevamos del sur, nuestra manera de hablar, nuestros vínculos que a esta altura son históricos y trascendentales. En los días de nuestra soledad, encandilamos otra vez el hogar y, por un minuto y, a pesar de las distancias, suprimimos el referente de la plaga.

El tiempo de la cocina distrae del tiempo de la pandemia. Pero la pandemia invita otras reflexiones sobre las políticas culturales de mi país. Y es cierto, debo decir: cada pueblo descubre su propia articulación de la crisis, sea lo que sea. En Estados Unidos, el tiempo de la protesta se inició después del asesinato del afroamericano George Floyd a manos de la policía. Los jóvenes, arriesgándolo todo, salen a la calle a protestar contra la violencia institucional; al mismo tiempo, se levanta la voz contra el racismo sistémico, acelerado, por cierto, por la mano del actual presidente. Es admirable ver a la gente en la calle, decimos los ancianos. Es mil veces mejor que en los años 60, comparte Angela Davis; debido a la ética de los jóvenes, la solidaridad que se comparte entre todos, la manera de unirse la gente de color con los blancos, confiamos en este primer paso hacia algo nuevo. Por su activismo callejero, las ciudades se parecen (por fin) a Santiago de Chile, a Buenos Aires, a Madrid.

Así vivimos el tiempo del coronavirus a doble compás: por un lado, protestamos la falta de un programa de salud pública adecuada que nos proteja del COVID (el alto número de muertos cae más sobre las comunidades minoritarias y 
las personas encarceladas. Ha habido casi 2000 muertos en la penitenciaria federal de San Quintín. Notable también es el número de ancianos que se mueren a diario en los asilos, son el 40\% de los muertos); por el otro, hay una alta conciencia política respecto de la opresión estatal, una demanda por justicia, un grito descomunal.

Las últimas palabras de George Floyd son "I can’t breathe" ("No puedo respirar"). Su asesinato, filmado en un celular por una chica de 17 años, anuncia a todo el mundo el drama del racismo en los EEUU; la supresión de derechos minoritarios, la violencia ejercida sin tregua contra la gente de color, la falta de protección judicial. Las asambleas masivas ofrecen en contravoz una vibrante señal de protesta. Allí en la plaza pública, se respira el aire de la libertad. No cabe duda de que fluyen los vientos del cambio social. La circulación del aire es literal y metafórico. Por un lado, enfocamos la falta de aire para la comunidad minoritaria, siempre victimizada por el poder, y por el otro, enfocamos el aire como elemento básico de vida, la base de nuestro intercambio y la solidaridad.

El aire me parece palabra clave para entender nuestra época. Abre sus alas a las posibilidades de entendernos en el mundo. El odio que nos asfixia, la represión que nos sofoca, la muerte; y, frente a ella, el flujo y la libre respiración, la posibilidad de mantenernos vivos, quizás de volver a nacer.

Hace años cuando estaba preparando un texto sobre poesía, buscaba una manera de centrar el gesto poético en el tono de la voz y la respiración. Es el aire, no la palabra, la base de la poesía, pensaba. El aire como base del ritmo es fuente de placer o dolor. Roland Barthes me guiaba en estas ideas, enfatizando la respiración como centro físico del ser. El placer de la voz, su capacidad de relacionarse con otro no depende de la palabra, escribía; más bien, remite a la materialidad del cuerpo que produce la lengua madre. El sonido, que emana del cuerpo, apela a una esencia inefable; es sentido como una pulsión, un ritmo, un timbre y se traducen como feelings anteriores a la razón. Es la señal física que da evidencia de la voz; produce a largo plazo significado y comprensión. Pero al cortar el aire, cortamos la voz, eliminamos al cuerpo hablante. Rompemos los vínculos entre el uno y el otro, destruimos la comunidad humana. Barthes por supuesto estaba interesado en cuestiones de la voz musical, la cantante de ópera entre otras, pero su trabajo en torno a las pulsiones de aire que conllevan al grano de la voz subraya una presencia física que necesitamos destacar: el cuerpo humano como base y centro productivo del habla. Desde el materialismo ineludible del cuerpo, se llega al lenguaje del ser humano: anuncia al mundo que yo "estoy aquí".

En poesía, el ritmo en verso se produce debido a los patrones de aire que el cuerpo hablante vuelve inteligibles. A partir de este cuerpo, tenemos susurros, pausas, pulsaciones, redondillas, endecasílabas. Resistimos el sistema de los códigos jurídicos, nos apartamos de la razón del estado. La voz, producto del aire 
y controlado por el cuerpo, registra una economía de impulsos vitales, supera la metafísica; insiste en la unicidad del cuerpo que produce su propio sonido.

"I can't breathe"; aire, sonido, verbo, vida. Al suprimir los soplos de aire que pasan por el cuerpo de George Floyd, también se corta la poesía, se corta el vínculo del ser humano con su entorno. Se corta el lenguaje hablado. Adriana Cavarero nos recuerda que en hebreo se utiliza el verbo "respirar" en lugar del verbo "decir". Ruab es respirar, es una manera de hacer sentido antes del sentido mismo. Respirar es natural, va en contra de cualquier jerarquía metafísica, va en contra de la ley. Respirar entonces es una práctica de pulsiones, sin uso de la razón. Es viento y espíritu, como será la pleura en griego. Durante estos meses de cuarentena, apartada del mundanal ruido, pensaba mucho en el corte de vida que sufrió George Floyd, en su negado acceso al aire. Y al mismo tiempo, corría el fenómeno del virus que, llegando a invadir los pulmones, también cortaba el acceso al aire y destruía la voz.

Los budistas creen que todos compartimos las mismas moléculas de aire. Yo respiro, tu exhalas. Entran en mi cuerpo las moléculas de aire que poco antes tú habías guardado en el tuyo. Al compartir el aire entre los dos, compartimos el sufrimiento y la pena; a través de la respiración, mi cuerpo toca el tuyo. Por cierto, es la base del contagio, pero también de la comunidad. Del flujo constante de aire, intercambiamos alegría y dolor; nos protegemos del mal. Al contrario, cortarle el aire a una persona es romper la cadena humana. Nos lleva por el camino de la aniquilación debido a nuestra falta de respeto por el aire y por los cuerpos vivientes.

Los textos sobre la plaga recuperan esta preocupación. Son un archivo de las ansiedades pertenecientes a la época en que vivimos. Escribiendo después de la influenza española de 1918, Pirandello redacta un cuento llamado "Il soffio" ("El soplo") donde enfoca la condición del ser humano en momentos de crisis. Pirandello narra la historia de un hombre que pensaba, en tiempos de la plaga, que él mismo fue responsable por el virus en circulación. Debido al soplo de su aliento, pensaba el personaje, se contaminaban las otras personas que estaban en su camino. Al principio, se encontró con cuatro personas; al día siguiente cada una murió. El señor pensaba que tenía la culpa, que había infectado a la gente con quien sostenía un mínimo de contacto. Un sueño de exterminio masivo le persigue y el señor le echa la culpa a su propia exhalación. Pasa el tiempo. Para comprobar su culpabilidad, el hombre sale otra vez a la calle para ver si su aliento sigue enfermando a la gente. Efectivamente, en la segunda vuelta de la plaga, el señor ve que muere más gente. El hombre se siente más culposo todavía; asume responsabilidad por los muertos. Vuelve a su casa y se mira en el espejo. No ve su cara; solo percibe el aire. El enigmático final disuelve toda fe en el contacto del uno con el otro. Al final, es solo el intercambio de aire que ejerce su poder. Pero el cuento de Pirandello también es 
una reflexión sobre la culpa, y sobre las maneras en las cuales tendemos a armar un equilibrio entre la conciencia y la verdad. ¿Quién se responsabiliza por la plaga? ¿Estamos, como sobrevivientes, cargados de una culpa colectiva? ¿La peste involucra al individuo y sus errores particulares o apela a un orden superior en el cual el estado, las instituciones del poder, incluso el orden divino, construyen las escenas de contagio, difunden la infección y la muerte? Pirandello pide que revisemos el papel del individuo y el Estado (recuerden que la ficción fue escrita durante el régimen fascista cuando Pirandello había jurado lealtad al partido del Duce). Como tal, la plaga deja abierta las implicancias de la cuestión social.

El COVID de nuestros días es un asalto contra el cuerpo, por cierto. Pero también exige otra manera de pensar la biopolítica en términos de la comunidad. Roberto Esposito en sus varios ensayos recientes explora este concepto empezando con la palabra munus (regalo, donación, dar al otro y recibir del otro al mismo tiempo, la reciprocidad). Esta es la fuente de immunitas, por un lado, y de communitas, por el otro. Inmunitas es cerrarse al otro, es cerrar las fronteras para prohibir que entren los desconocidos en mi espacio privado, es renegar el regalo del otro. Implica construir paredes. Communitas, por contraste insiste en la alteridad como factor constituyente del yo. Sin communitas no vivimos; hay que aceptar al otro para sobrevivir. Y para sostenerla, hay que correr los riesgos que este gesto implica. Para escaparnos de la muerte necesitamos estar en contacto con el otro. Una defensa de la comunidad, del gesto comunal. Este es el esfuerzo por sostener la comunidad que producirá nuevos significados; desde la comunidad, y en contacto con el otro, se produce lenguaje y pensamiento. Sin la compañía del otro, no seremos capaces de crear.

El cuento de Pirandello de 1931 balancea estas propuestas. Estar aislado (que significa la autodestrucción) o participar de la comunidad humana como garantía de vida, para construir algo nuevo. Dejar que fluya el aire o construir una muralla de piedra para que no entre lo desconocido. La soledad versus la expansión de contactos que prometen la sobrevivencia. El modelo se hace visible en la época de plaga cuando también el racismo sistémico de los Estados Unidos separa y divide a la gente. Y aquí no es curioso que la metáfora de la piedra sea concurrente con la del aire. La piedra es sinónimo de la muralla que se quiere construir en la frontera con México para que no entren los migrantes en busca de una nueva vida. La piedra también recuerda la destrucción actual de los monumentos que están en los parques públicos en honor a aquellas figuras políticas y culturales que defendían la esclavitud. Me refiero a las estatuas de las coroneles militares de la Guerra de Secesión del Sur y también a los monumentos que honraban a Colón, Junípero Serra, e incluso Cervantes. ¿Los intentos de destrucción de las estatuas nos llevarán a una nueva barbarie, como afirman algunos? ¿O serán un deseo de reamar las políticas 
de la memoria para que coincidan con el flujo del aire? Denunciar la represión, enfrentar la muerte, construir la comunidad humana para sobrevivir.

Sin duda, el asesinato de George Floyd y hoy, al momento de esta escritura, el asalto a balazos a Jacob Blake, los incendios en California que nos dejan en la oscuridad anaranjada y sofocante: todo sirve para repensar el flujo, y la necesidad de continuar abriendo las puertas al contacto humano, de dejar correr el aire. De poner en oposición al silencio de piedra la urgencia de la brisa vital. 